\title{
Measurement of Serum EGFR $m R N A$ Expression is a Reliable Predictor of Treatment Response and Survival Outcomes in Non- Small Cell Lung Cancer
}

\author{
Anant Mohan ${ }^{1 *}$, Ashraf Ansari ${ }^{1}$, Mirza Masroor ${ }^{2}$,Alpana Saxena ${ }^{2}$, R M Pandey ${ }^{3}$, \\ Ashish Upadhyay ${ }^{3}$, Kalpana Luthra ${ }^{3}$, G C Khilnani', Deepali Jain ${ }^{4}$, Rakesh \\ Kumar $^{5}$, Randeep Guleria ${ }^{1}$
}

\begin{abstract}
Background: EGFR over-expression plays a key role in the development and progression of lung cancer. However, its status as a prognostic biomarker for survival outcomes is unclear. Objectives: To evaluate the prognostic utility of serum EGFR mRNA expression in Non-Small cell lung cancer (NSCLC) for treatment response and survival. Methods: $E G F R$ mRNA levels were determined in serum using quantitative reverse transcriptase polymerase chain reaction (qRT-PCR). Based on ROC curve, a cut off value of 16.0-fold increase was selected to categorize patients into low EGFR $(\leq 16.0)$ and high EGFR $(>16.0)$ groups. Results: A total of 350 subjects were included $(78.3 \%$ males), with mean $( \pm \mathrm{SD})$ age of $57.1( \pm 11.2)$ years, and including $247(70.6 \%)$ adenocarcinoma (ADC). Majority $(73.1 \%)$ had metastatic (stage IV) disease. Patients had higher pre-treatment serum EGFR mRNA levels than controls [median fold-increase (min, max), 16.2 (1.9, 66.7). Serum EGFR mRNA levels significantly reduced in those who achieved objective response and disease control. Significantly longer OS and PFS was observed in subjects having baseline EGFR $m R N A$ expression $\leq 16.0$ fold- increase compared to those with $>16.0$ fold- increase [median (95\% CI) OS: $25.0(14.9, \mathrm{NR})$ versus $7.7(6.3,8.9)$ months; HR $(95 \% \mathrm{CI}) 2.9(2.3,4.0), \mathrm{p}<0.001$; and PFS: $9.9(7.1,11.5)$ versus $6.0(4.1,7.5)$ months; HR $(95 \%$ CI $) 1.8(1.3,2.4), \mathrm{p}<0.001]$. Conclusion: Serum EGFR $m R N A$ expression is a useful parameter for predicting treatment response and survival outcomes in NSCLC.
\end{abstract}

Keywords: $E G F R$ expression- lung cancer- survival

Asian Pac J Cancer Prev, 21 (11), 3153-3163

\section{Introduction}

The Epidermal Growth Factor Receptor (EGFR) appears to play a key role in the development and progression of various cancers, including lung. Alterations in $E G F R$ in the form of overexpression, amplification, or mutations are postulated to contribute to the development or propagation of lung cancer by enhancing cellular proliferation, apoptosis inhibition, and angiogenesis (Ciardiello and Tortora, 2003; Gazdar, 2009). However, existing literature regarding prognostic role of EGFR expression remains inconsistent, with some reports indicating that $E G F R$ expression is associated with poor survival (Li et al., 2008; Sun et al., 2015; Chang et al., 2017) while others have reported no prognostic association (Hirsch et al., 2017; Brabender et al., 2001). Furthermore, most existing studies have been done in the resected tissue specimens of early stage lung cancer (Nakamura et al., 2006; Meert et al., 2002). However, in most countries including India, lung cancer is diagnosed at a relatively advanced stage when they are not candidates for surgical resection, hence resected specimens are unavailable (Chandra et al., 2009; Guleria et al., 1997; Jindal, 1990). In this regard, blood (serum / plasma) is being considered an attractive alternative to tissue for $E G F R$ expression testing (Lee, 2006; Zhuo et al., 2014). Since sparse literature exists regarding the value of EGFR expression in blood of advanced stage lung cancer patients, the prognostic significance of $E G F R$ expression in lung cancer and, more importantly, its ability to predict response to anti-EGFR therapies, are currently subjects of active research. In an attempt to evaluate the above-mentioned lacunae, the present study was planned with an aim to (a) evaluate the prognostic utility of serum EGFR $m R N A$ expression

${ }^{1}$ Department of Pulmonary Medicine and Sleep Disorders, All India Institute of Medical Sciences, New Delhi, India. ${ }^{2}$ Department of Biochemistry, Maulana Azad Medical College, New Delhi, India. ${ }^{3}$ Department of Biostatistics, All India Institute of Medical Sciences, New Delhi. ${ }^{4}$ Department of Pathology, All India Institute of Medical Sciences, New Delhi, India. ${ }^{5}$ Department of Nuclear Medicine, All India Institute of Medical Sciences, New Delhi, India. *For Correspondence: anantmohan@yahoo.com 
in Non-Small cell lung cancer (NSCLC).

\section{Materials and Methods}

\section{Patients and Methods}

This was a prospective observational study conducted from June 2015 till $31^{\text {st }}$ December 2017 at a tertiary level academic health centre in North India. Newly diagnosed, treatment naïve patients with Non-small cell lung cancer (NSCLC) were included. Patients with concurrent cancer at any other site, or those who were planned for surgery or who had previously received any form of chemotherapy were excluded. The control group included 50 healthy subjects matched for age, sex, and smoking status and without any clinical evidence of malignant disease and no recent acute infection (within the past six weeks).

After obtaining informed written consent, relevant clinical and demographic details were entered a pre-designed structured proforma. For smoking burden, one pack-year was calculated by considering one pack having 20 cigarettes smoked every day for 1 year. For bidi smokers (a local form of tobacco inhalation through rolled tendu leaves), smoking index (S.I.) was calculated by multiplying the number of bidis smoked per day multiplied by number of years smoked (Shimkhada and Peabody, 2003; Singh et al., 2012; Jindal et al., 1982; Reddy and Reddy, 2004) Ex / reformed smokers were defined as those who had quit smoking at least six months previously. Performance status was assessed using a) Karnofsky Performance Scale (KPS), (Karnofsky and JH, 1949) and b) Eastern Co-operative Oncology Group (ECOG) Scale (Oken et al., 1982). In addition, history of prior anti-tubercular treatment was enquired, especially if taken during the current episode of symptoms. Details of diagnostics and staging investigations were recorded. Staging was done according to American Joint Committee for Cancer Control (AJCC) -TNM staging scheme $\left(7^{\text {th }}\right.$ edition) upto $31^{\text {st }}$ December 2016 and as per the joint American Joint Committee for Cancer Control (AJCC) - International Association for Study of Lung Cancer (IASLC) - Union for International Cancer Control (UICC) - 8th edition recommendations from $1^{\text {st }}$ January 2017 (Brierley et al., 2017; Amin et al., 2017; Rami-Porta, 2016; Detterbeck et al., 2017).

Peripheral venous blood sample $(3 \mathrm{ml})$ was collected in a plain vial from each patient before initiating treatment, and from the control subjects, after written informed consent. The sample was left standing for 20-30 minutes at room temperature and allowed to clot. Serum was separated by centrifugation of blood sample at $1,800 \times \mathrm{g}$ for $10 \mathrm{~min}$. and removed by Pasteur pipette in a separate eppendorf tube. The serum was stored at $-80^{\circ} \mathrm{C}$ until further analysis.

\section{Determination of EGFR $m R N A$ Expression in serum}

Quantitative real -time polymerase chain reaction (qRT-PCR) was carried out to quantify EGFR expression by measuring the levels of EGFR mRNA in serum of NSCLC patients and healthy controls, using specific set of primers and SYBR green I technology in the RotorGene Q Real-time PCR cycler (QIAGEN). EGFR $m R N A$ expression was determined using the relative quantification PCR double delta cycle threshold $(\Delta \Delta \mathrm{Ct})$ method (Livak and Schmittgen, 2001)as per the following steps: (1) RNA extraction using Trizol method; (Chomczynski and Mackey, 1995)(2) cDNA synthesis using cDNA synthesis kit (Thermo Scientific, USA); and (3) verification of cDNA integrity using $\beta$ actin gene as internal control. The PCR products were analysed on $2.0 \%$ agarose gel, stained with ethidium bromide, visualized and photographed in a ultraviolet (UV) Gel documentation system. Quantitative Real Time PCR (qPCR) for EGFR and $\beta$-Actin was performed using specific primers (Bieche et al., 2003).

\section{Calculation of EGFR Expression}

The Ct or threshold cycle value is the number of cycles required for the fluorescent signal to cross the threshold. $\mathrm{Ct}$ levels are inversely proportional to the amount of target nucleic acid in the sample. The expression level is calculated as per the following formula:

1) Normalize $\mathrm{Ct}^{*}$ (Target gene) to $\mathrm{Ct}$ (reference gene) $\Delta \mathrm{Ct}($ Control $)=\mathrm{Ct}$ (target gene $)-\mathrm{Ct}($ reference gene $)$ $\Delta \mathrm{Ct}$ (Patient) $=\mathrm{Ct}$ (target gene) $-\mathrm{Ct}$ (reference gene) 2) Normalize $\Delta \mathrm{Ct}$ of patient sample to $\Delta \mathrm{Ct}$ of healthy control.

$\Delta \Delta \mathrm{Ct}=\Delta \mathrm{Ct}$ (Patient) $-\Delta \mathrm{Ct}$ (control)

3) Calculate expression ratio or fold difference.

Ratio/Fold change $=2^{-\Delta \Delta \mathrm{Ct}}$

$(* \mathrm{Ct}=$ Cycle threshold $)$

Serum EGFR expression was determined at 3 months following treatment either with oral Gefitinib tablet (250 mg once daily in the subgroup of tissue EGFR mutation-positive patients), or with conventional chemotherapy (four cycles of injectable Carboplatin plus Paclitaxel at 3-weekly intervals in patients with tissue-negative EGFR mutations and Squamous cell cancer). Clinical response was evaluated after 2-3 months in Gefitinib group and after 4 cycles of chemotherapy in the chemotherapy group by repeat imaging with CT scan of chest and upper abdomen or by $18 \mathrm{~F}$ - Fluorodeoxyglucose (FDG) PET/CT scanning. Treatment response was assessed using the RECIST 1.1 criteria (Eisenhauer et al., 2009)and classified as one of the following: Complete Response (CR); Partial response (PR); Progressive Disease (PD); or Stable Disease (SD). Subsequently, Objective Response Rate (ORR) was calculated as the proportion of subjects with a tumor size reduction of a predefined for a minimum time period defined as the sum of Complete Response (CR) plus Partial response (PR) (Pazdur, 2008). Disease Control Rate (DCR) was defined as the sum of Complete Response (CR), Partial response (PR), and Stable disease (SD) (Nakashima et al., 2016; Claret et al., 2014). For the purpose of analysis, subjects who achieved CR or PR were termed as "Responders", while those with SD or PD were termed "Non-responders".

\section{Evaluation of survival parameters}

All patients were followed up using appropriate imaging (CT-PET scans / CT chest) every 3-4 months for a period of one year from date of diagnosis. Subjects were asked to follow up periodically in the clinic; those 
who missed their visits were contacted by telephone to ascertain their clinical status and all relevant clinical details were recorded; in case of death of the patient, the date of death was recorded. In situations where no contact could be established after repeated phone calls, the last date of known contact by phone or by hospital visit was used for calculating survival outcome parameters. Last date of follow-up was kept as $31^{\text {st }}$ December 2017 and data was censored at this date. The following clinical outcomes were determined: (a) Overall survival (OS): Defined as the time period from date of diagnosis till date of death or last date of known follow - up (US Dept. of Health, 2007). The patients who survived at the time of study closure had their survival time censored to that date; and (b) Progression free survival (PFS): Defined as the time from date of starting treatment till the date of documented disease progression or death, or last date of follow up. The patients who were progression - free at the time of study closure had their time to progression censored to that date.

The sample size of the study was computed to determine the role of serum EGFR $m R N A$ expression at baseline on improvement in survival in patients on treatment, at 12 months based on the initial data obtained at 12 months follow up of the first 50 patients in the study. Keeping an estimated proportion of 1-year survival in the low $E G F R$ expression group as $75 \%$ and $50 \%$ in the high $E G F R$ expression group, with hazard ratio (HR) of 1.94, $80 \%$ power and alpha - error of $5 \%$, the required number of subjects in each of the 2 groups (low / high EGFR) were estimated to be 61 . Considering that approx. $1 / 3$ of the patients would not be initiated on treatment and some patients may be censored during follow-up, we would have to enrol minimum 250 subjects in total. 50 normal age, gender and smoking matched control subjects were included for comparison of serum EGFR expression.

\section{Results}

During the study period, a total of 395 subjects were screened, of whom 45 were subsequently excluded (previous / ongoing chemotherapy $=18$; refusal of consent $=16$; tumor morphology not defined=11). Finally, 350 subjects were included for evaluation and analysis. Of these, 247 (70.6\%) had adenocarcinoma (ADC) and 103 (29.4\%) had squamous cell carcinoma (SCC) morphology. The demographic characteristics of the study group is shown in Table 1 . The study group comprised 274 males

Table 1. Demographic Characteristics of the Study Subjects

\begin{tabular}{|c|c|c|c|}
\hline Variable & Adenocarcinoma $(n=247)$ & Squamous cell $(n=103)$ & Total $(n=350)$ \\
\hline Age (years) & $55.4 \pm 11.6$ & $60.9 \pm 9.0$ & $57.1 \pm 11.2$ \\
\hline \multirow[t]{2}{*}{ Duration of symptoms (days) } & $155.2 \pm 109.1$ & $173.1 \pm 125.9$ & $160.4 \pm 114.4$ \\
\hline & $120(75.40)$ & $150(75.40)$ & $120(75.40)$ \\
\hline \multicolumn{4}{|l|}{ Age category } \\
\hline$\leq 50$ years & $89(36.1)$ & $14(13.6)$ & $103(29.4)$ \\
\hline $51-65$ years & $114(46.1)$ & $59(57.3)$ & $173(49.4)$ \\
\hline$\geq 66$ years & $44(17.8)$ & $30(29.1)$ & $74(21.2)$ \\
\hline Gender & $178(72.1)$ & $96(93.2)$ & \\
\hline Males & $69(27.9)$ & $7(6.8)$ & $274(78.3)$ \\
\hline Females & & & $76(21.7)$ \\
\hline \multicolumn{4}{|l|}{ Smoking Status } \\
\hline Non-smokers & $105(42.1)$ & $7(6.8)$ & $112(31.7)$ \\
\hline Current / ex- smokers & $142(57.9)$ & $96(93.2)$ & $238(68.3)$ \\
\hline \multicolumn{4}{|l|}{ Smoking Index $(\mathrm{n}=238) *$} \\
\hline$\leq 250$ & $50(35.3)$ & $22(22.9)$ & $72(30.3)$ \\
\hline $251-500$ & $44(30.9)$ & $27(28.1)$ & $71(29.8)$ \\
\hline$>500$ & $48(33.8)$ & $47(49.0)$ & $95(39.9)$ \\
\hline \multicolumn{4}{|l|}{ Stage } \\
\hline Non-metastatic (I-III) & $48(19.4)$ & $46(44.7)$ & $94(26.9)$ \\
\hline Metastatic (IV) & $199(80.6)$ & $57(55.3)$ & $256(73.1)$ \\
\hline \multicolumn{4}{|l|}{ KPS } \\
\hline $40-70$ & $100(40.5)$ & $53(51.5)$ & $153(43.7)$ \\
\hline $80-100$ & $147(59.5)$ & $50(48.5)$ & $197(56.3)$ \\
\hline \multicolumn{4}{|l|}{ ECOG score } \\
\hline $0 / 1$ & $138(55.9)$ & $52(50.5)$ & $190(54.3)$ \\
\hline 2 & $82(33.2)$ & $38(36.9)$ & $120(34.3)$ \\
\hline 3 & $27(10.9)$ & $13(12.6)$ & $40(11.4)$ \\
\hline
\end{tabular}

All values expressed as number (\%), median (min, max), or mean $\pm \mathrm{SD}$; Excluding lifetime non-smokers. Smoking index was calculated by multiplying the number of bidis smoked per day with the number of years smoked 

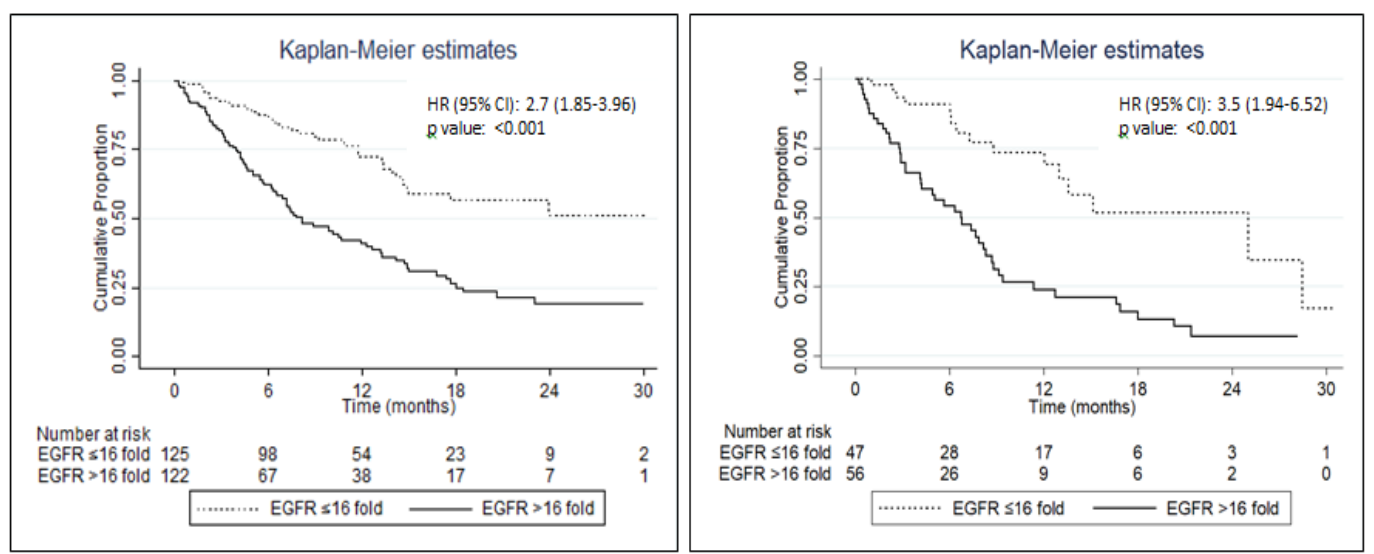

Figure 1. Overall Survival Time in Adenocarcinoma (panel A) and Squamous Cell (Panel B) Lung Cancer Subjects Having low $(\leq 16.0)$ and high $(>16.0)$ Baseline Serum EGFR mRNA Levels. OS, overall survival; HR, hazard ratio; $\mathrm{CI}$, confidence interval; NR, not reached; EGFR values expressed as fold-increase over control values

(78.3\%) overall, with mean (SD) age of $57.1(11.2)$ years. Majority of subjects $(68.3 \%)$ were either current or reformed smokers. The mean (SD) symptom duration of the study group was 160.4 (114.4) days, with median duration of 120 days (range, 7 to 540 days).

Among the total 350 subjects, $256(73.1 \%)$ had metastatic (stage IV) disease (80.6\% of ADC and $55.3 \%$ of SCC). The commonest metastatic sites were the lungs (28.9\%), pleural effusion (26.9\%), and bone (26\%), followed by brain $(14 \%)$, adrenals $(12.3 \%)$, and liver (7.4\%). Other metastatic sites included extra thoracic lymph nodes $(\mathrm{n}=12)$, and kidney, parotid, pancreas and thyroid (1 patient each).

Of the total 350 subjects, 267 (76.3\%) were initiated on treatment. Of these, 203 (58\%) subjects were initiated on chemotherapy (51\% in ADC and 74.8\% in SCC), while 64 patients $(25.9 \%$, all $\mathrm{ADC})$ received oral Tyrosine kinase inhibitors (TKIs) in the form of Gefitinib tablets. The remaining subjects received best supportive care or opted for alternative modalities of treatment. Radiotherapy was administered for palliative purposes to 52 patients (14.9\%) and with curative intent in $8(2.3 \%)$ patients.
Of the total subjects, response to treatment was evaluated in 174 (130 in chemotherapy group and 44 in the Gefitinib group). Overall, majority of patients (57.5\%) achieved a partial response (PR) [56.1\% in chemotherapy group and $61.3 \%$ in the Gefitinib group]. Objective response (OR) was achieved in 102 patients $(58.6 \%)$ of the total group $(57.7 \%$ in chemotherapy group and $61.3 \%$ in the Gefitinib group) while disease control (DC) was achieved in 126 patients $(72.4 \%)$ of the total group $(71.5 \%$ in chemotherapy group and $75.0 \%$ in the Gefitinib group).

By the end of the study follow up period, out of 350 subjects, 179 (51.1\%) did not survive. The median overall survival (OS) time was 13.2 months (95\% CI, 10.9 to 14.9 months). The OS time of ADC was significantly greater than OS time in SCC [median $(95 \% \mathrm{CI}), 14.6$ (11.9, $17.6)$ versus $8.8(7.3,13.6)$ months respectively, log-rank $\mathrm{p}$-value $=0.01]$. The hazard of mortality in SCC subjects was 1.5 times higher as compared to the ADC subjects [HR (95\% CI): $1.5(1.1,2.0), \mathrm{p}=0.01]$.

Disease progression occurred in $163(68.2 \%)$ of 267 patients who were initiated on any treatment. The median PFS time of the whole study group was 7.5 months (95\%

Table 2. Serum EGFR mRNA Expression at Baseline and after Treatment

\begin{tabular}{|c|c|c|c|c|c|c|}
\hline Histology type & Parameter & $\begin{array}{c}\text { Baseline levels } \\
\text { (fold - increase over controls) }\end{array}$ & $\begin{array}{c}\text { Post treatment } \\
\text { levels }\end{array}$ & p-value & $\begin{array}{l}\text { Absolute difference } \\
\text { (pre-post) }\end{array}$ & $\%$ difference \\
\hline \multirow[t]{4}{*}{ Adeno } & Mean \pm SD & $17.7 \pm 8.2$ & $11.5 \pm 8.2$ & $<0.001$ & $4.3 \pm 10.8$ & $9.9 \pm 76.9$ \\
\hline & Median & 16 & 9.2 & & 4.2 & 34.3 \\
\hline & $(\min , \max )$ & $(1.9,66.7)$ & $(3.4,56.5)$ & & $(-40.3,62.2)$ & $(-340.7,93.2)$ \\
\hline & $\mathrm{n}$ & 247 & 118 & & 118 & \\
\hline \multirow[t]{4}{*}{ Squamous } & Mean \pm SD & $17.5 \pm 7.7$ & $11.5 \pm 8.0$ & $<0.001$ & $5.1 \pm 9.2$ & $20.9 \pm 59.2$ \\
\hline & Median & 16.9 & 9.3 & & 5.6 & 36.7 \\
\hline & $(\min , \max )$ & $(4.1,42.8)$ & $(2.5,41.8)$ & & $(-16.7,33.6)$ & $(-178.9,78.4)$ \\
\hline & $\mathrm{n}$ & 103 & 43 & & 43 & 43 \\
\hline $\mathrm{p}$ value & & 0.94 & 0.81 & & 0.72 & 0.39 \\
\hline \multirow[t]{4}{*}{ Total (all subjects) } & Mean \pm SD & $17.6 \pm 8.1$ & $11.5 \pm 8.1$ & $<0.001$ & $4.5 \pm 10.4$ & $12.8 \pm 72.6$ \\
\hline & Median & 16.2 & 9.2 & & 4.45 & 34.9 \\
\hline & $(\min , \max )$ & $(1.9,66.7)$ & $(2.5,56.5)$ & & $(-40.3,62.2)$ & $(-340.8,93.3)$ \\
\hline & $\mathrm{n}$ & 350 & 161 & & 161 & 161 \\
\hline
\end{tabular}

All values expressed as mean $\pm \mathrm{SD}$, or median (min, max) 

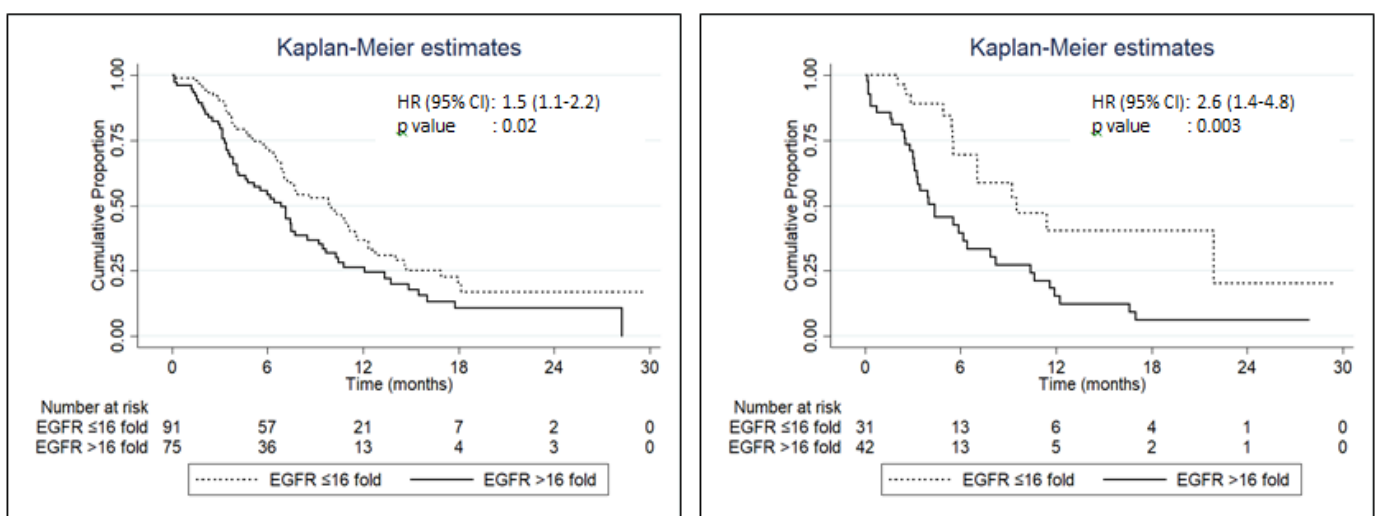

Figure 2. Progression-Free Survival Time in Adenocarcinoma (Panel A) and Squamous Cell (Panel B) Lung Cancer Subjects Having Low $(\leq 16.0)$ and High $(>16.0)$ Baseline Serum EGFR mRNA Levels. PFS, Progression-free survival; HR, hazard ratio; CI, confidence interval; NR, not reached; EGFR values expressed as fold-increase over control values

CI, 6.6-9.2 months). The PFS time of ADC was not significantly different from that of SCC patients [median $(95 \% \mathrm{CI}), 7.7$ months $(6.9,9.9)$ vs $6.2(4.9,9.5)$ months respectively); HR $(95 \% \mathrm{CI}), 1.2(0.8,1.6), \mathrm{p}=0.41]$.

Serum EGFR mRNA expression of the study group before and after treatment

EGFR $m R N A$ expression was measured in serum at baseline and after treatment in 247 Adenocarcinoma (ADC) and 103 Squamous cell carcinoma (SCC) subjects. Throughout this document, patient EGFR mRNA values are expressed as fold-increase in levels compared to the control values. Figure 1 shows a representative picture of (a) RNA extraction; (b) cDNA synthesis from RNA; (c) RT-PCR amplification graph and (d) and melting curve during EGFR mRNA determination.

Following treatment, EGFR levels reduced significantly in males as well as females, in all age categories and within each of the three smoker categories (Table 2). Overall, the median ( $\min , \max$ ) fold - increase in baseline EGFR $m R N A$ expression compared to controls was 16.2 (1.9,
66.7), which reduced significantly following treatment to $9.2(2.5,56.5)[\mathrm{p}<0.001]$. Individually in ADC and SCC, the baseline EGFR $m R N A$ expression was elevated and reduced significantly following treatment. However, the EGFR mRNA levels were similar between ADC and SCC groups at baseline as well as following treatment.

No significant difference existed in serum EGFR mRNA levels between ADC and SCC either at baseline [median (min, max), $16.0(1.9,66.7)$ and $16.9(4.1,42.8)$ respectively, $\mathrm{p}=0.84$ ], or after treatment [median (min, $\max ), 9.2(3.4,56.5)$ and $9.3(2.5,41.8)$ respectively, $\mathrm{p}=0.76]$ or between subjects with metastatic disease and non-metastatic disease. Similarly, no association was seen between EGFR mRNA and KPS or ECOG scores. Following treatment, serum EGFR mRNA levels reduced significantly in both the chemotherapy as well as the Gefitinib groups $(\mathrm{p}<0.001)$ (Table 3$)$.

Serum EGFR mRNA expression as a predictor of treatment response

Pre-treatment serum EGFR $m R N A$ levels were similar

Table 3. Change in Serum EGFR mRNA Expression Levels Based on Treatment Modality Received

\begin{tabular}{|c|c|c|c|c|c|}
\hline $\begin{array}{l}\text { Treatment } \\
\text { modality }\end{array}$ & & $\begin{array}{l}\text { Baseline (Pre- treatment) EGFR } \\
\text { mRNA expression (fold- increase) }\end{array}$ & $\begin{array}{l}\text { Post treatment EGFR mRNA } \\
\text { expression (fold- increase) }\end{array}$ & $\begin{array}{c}\mathrm{p} \\
\text { value }\end{array}$ & $\begin{array}{l}\text { Absolute reduction } \\
\text { (pre - post) }\end{array}$ \\
\hline \multirow[t]{4}{*}{ No treatment } & $\mathrm{N}$ & 83 & $\mathrm{n}=0$ & ---- & $\mathrm{n}=0$ \\
\hline & Mean \pm SD & $19.6 \pm 9.5$ & & & \\
\hline & Median & 17.5 & & & \\
\hline & $(\min , \max )$ & $(4.1,56.1)$ & & & \\
\hline \multirow[t]{4}{*}{ Chemotherapy } & $\mathrm{N}$ & 203 & 120 & $<0.001$ & 120 \\
\hline & Mean \pm SD & $16.9 \pm 7.1$ & $11.4 \pm 7.8$ & & $4.3 \pm 8.9$ \\
\hline & Median & 15.7 & 9.2 & & 4.7 \\
\hline & $(\min , \max )$ & $(2.3,42.8)$ & $(2.4,56.5$ & & $(-37.2,33.6)$ \\
\hline \multirow[t]{5}{*}{ TKI } & $\mathrm{N}$ & 64 & 41 & 0.001 & 41 \\
\hline & Mean \pm SD & $17.1 \pm 8.6$ & $11.8 \pm 9.2$ & & $4.9 \pm 13.9$ \\
\hline & Median & 16.6 & 9.2 & & 4.2 \\
\hline & $(\min , \max )$ & $(1.9,66.7)$ & $(3.8,56.5)$ & & $(-40.3,62.2)$ \\
\hline & p-value & 0.03 & 0.94 & & 0.74 \\
\hline
\end{tabular}




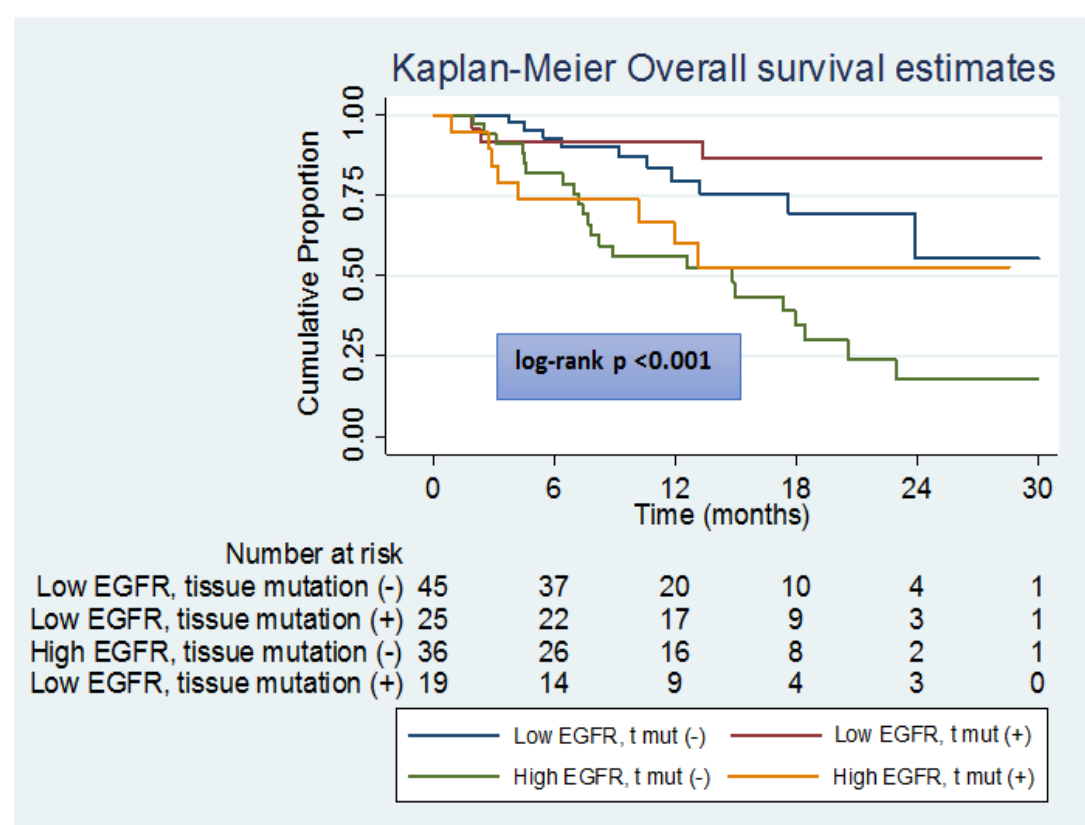

Figure 3. OS in Patients with High and Low Baseline EGFR mRNA Levels Based on Their Tissue Mutation Status

Table 4. Serum EGFR mRNA Levels based on Objective Response, Disease Control and Mortality in NSCLC

\begin{tabular}{|c|c|c|c|c|}
\hline Variable & & $\begin{array}{c}\text { Pre- treatment serum EGFR mRNA } \\
\text { levels (fold-increase) }\end{array}$ & $\begin{array}{l}\text { Post -treatment serum } \\
\text { EGFR mRNA levels }\end{array}$ & p-value \\
\hline Treatment Response & $\mathrm{N}$ & 102 & 97 & $<0.001$ \\
\hline \multirow[t]{3}{*}{ Responders } & Mean \pm SD & $15.7 \pm 8.1$ & $10.2 \pm 6.9$ & \\
\hline & Median & 14.9 & 8.6 & \\
\hline & $(\min , \max )$ & $(1.9,66.7)$ & $(2.5,56.5)$ & \\
\hline \multicolumn{5}{|l|}{ Non-responders } \\
\hline & $\mathrm{N}$ & 72 & 64 & 0.009 \\
\hline & Mean \pm SD & $16.5 \pm 7.3$ & $13.5 \pm 9.4$ & \\
\hline & Median & 15.3 & 10.9 & \\
\hline & $(\min , \max )$ & $(2.3,38.5)$ & $(2.5,56.5)$ & \\
\hline & p-value & 0.39 & 0.01 & \\
\hline Disease Control & $\mathrm{N}$ & 126 & 120 & $<0.001$ \\
\hline \multirow[t]{3}{*}{ Yes } & Mean \pm SD & $15.8 \pm 7.7$ & $9.8 \pm 6.3$ & \\
\hline & Median & 14.8 & 8.7 & \\
\hline & $(\min , \max )$ & $(1.9,66.7)$ & $(2.5,56.5)$ & \\
\hline \multirow[t]{5}{*}{ No } & p-value & 48 & 41 & 0.62 \\
\hline & Mean \pm SD & $16.8 \pm 8.0$ & $16.2 \pm 10.7$ & \\
\hline & Median & 15.8 & 12.3 & \\
\hline & $(\min , \max )$ & $(1.9,66.7)$ & $(2.9,56.5)$ & \\
\hline & p-value & 0.48 & $<0.001$ & \\
\hline Mortality & $\mathrm{N}$ & 179 & 48 & $<0.001$ \\
\hline \multirow[t]{3}{*}{ Yes } & Mean \pm SD & $21.1 \pm 8.5$ & $11.8 \pm 9.6$ & \\
\hline & Median & 19.3 & 8.9 & \\
\hline & $(\min , \max )$ & $(8.3,66.7)$ & $(4.1,56.5)$ & \\
\hline \multirow[t]{5}{*}{ No } & $\mathrm{N}$ & 171 & 113 & $<0.001$ \\
\hline & Mean \pm SD & $13.9 \pm 5.7$ & $11.4 \pm 7.5$ & \\
\hline & Median & 13.6 & 9.7 & \\
\hline & $(\min , \max )$ & $(1.9,27.1)$ & $(2.5,56.5)$ & \\
\hline & p-value & $<0.001$ & 0.62 & \\
\hline
\end{tabular}

All values expressed as mean $\pm \mathrm{SD}$ or median (min, max)

3158 Asian Pacific Journal of Cancer Prevention, Vol 21 


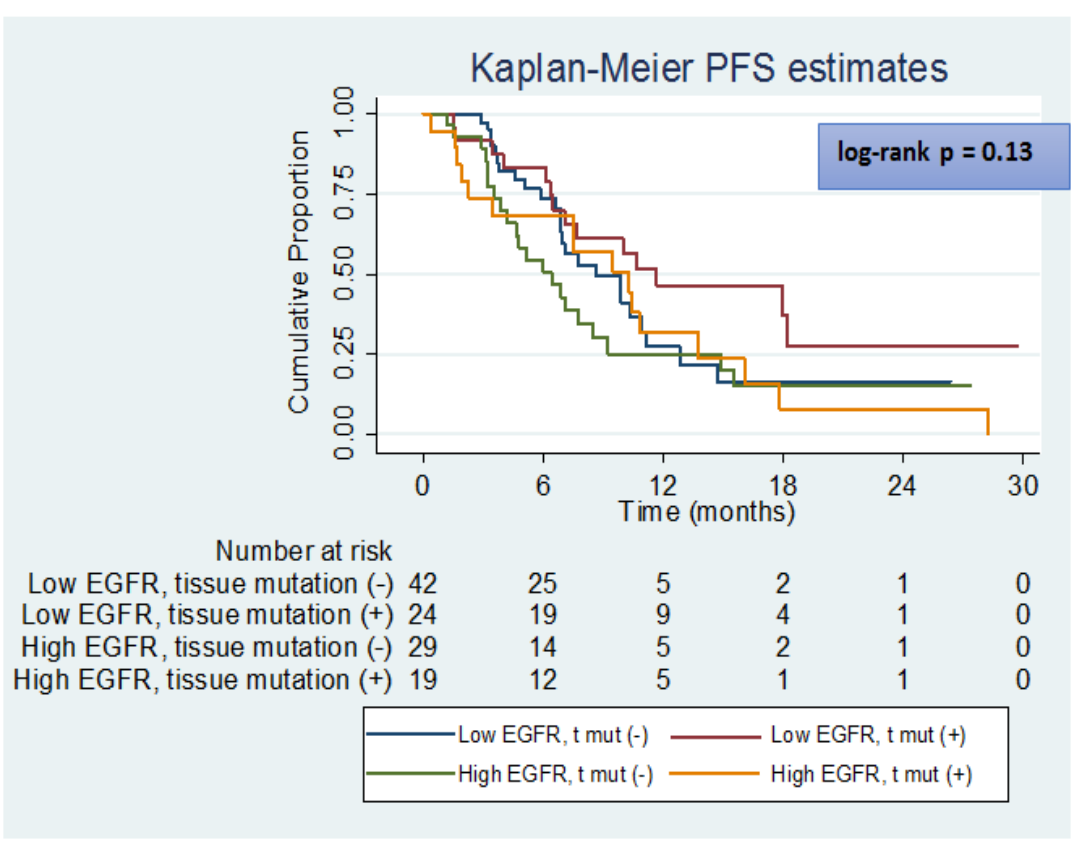

Figure 4. PFS of Patients with High and Low Baseline EGFR mRNA Levels based on Their Tissue Mutation Status

in responders and non-responders (Table 4). However, post-treatment EGFR $m R N A$ was significantly higher in non-responders, i.e., those who did not achieve Objective response $(\mathrm{p}=0.01)$. Comparison of pre and post-treatment EGFR mRNA levels revealed that significant reduction occurred in both responders as well as non-responders $(\mathrm{p}<0.001$ and $\mathrm{p}=0.009$ respectively). However, subjects who failed to achieve disease control did not demonstrate reduction in EGFR levels.

Significant reduction in EGFR mRNA levels was observed from baseline to post-treatment both in the survivors as well as the subjects who did not survive. However, the baseline serum EGFR mRNA expression levels in the subjects who died were significantly higher than those who survived (Table 4).

The Receiver Operating Characteristics (ROC) curve was used to determine predictive value of baseline serum EGFR mRNA levels to predict mortality and a cut off value of 16.0 was selected, as it corresponded to higher sensitivity and specificity. The OS time was significantly greater in subjects with baseline serum EGFR $m R N A$ levels $\leq 16.0$-fold-increase compared to those with levels $>16.0$-fold-increase [median $(95 \%$ CI) OS, 25.0 (14.9, NR) vs $7.7(6.3,8.9)$ months respectively; HR $(95 \% \mathrm{CI})$ $2.9(2.1,4.0), \log$-rank $\mathrm{p}<0.001]$. The patient group with baseline serum EGFR $m R N A$ levels $>16.0$ had a 2.9 times higher risk of mortality compared to those with baseline EGFR levels $\leq 16.0$. Similar results were found in ADC and SCC (Figure 1); ADC and SCC with baseline serum EGFR expression $>16.0$ had 2.7 times and 3.5 times higher risk of mortality respectively compared to those with baseline expression $\leq 16.0$.

Similarly, the PFS time was significantly greater in subjects with baseline serum EGFR $m R N A$ expression levels $\leq 16.0$ fold compared to those with levels $>16.0$-fold (Figure 2); the subjects with baseline serum EGFR expression $>16.0$ had a 1.8 times higher risk of disease progression compared to those with expression $\leq 16.0$.
Similar findings were obtained in subgroups of ADC and SCC (Figure 3A and 3B) with subjects with baseline serum EGFR $m R N A$ expression $>16.0$ demonstrating a 1.5 and 2.6-times higher risk of disease progression respectively compared to those with expression $\leq 16.0$.

\section{Discussion}

Our results show that baseline (pre-treatment) serum EGFR mRNA levels in NSCLC were elevated compared to the control group, and they reduced significantly following treatment. Over-expression of EGFR in lung cancer has been documented previously, although most studies used tissue specimens for EGFR testing. In comparison to normal lung tissue and para-cancerous tissue, lung cancer cells show significantly higher EGFR expression (Brabender et al., 2001; Li et al., 2011). The degree of $E G F R$ expression has been widely variable and ranges between 32\%- 81\% (Li et al., 2008; Fontanini et al., 1998; Gaber et al., 2014; Rusch et al., 1997). In a meta-analysis of 18 studies, 1,441 of 2,972 (48.5\%) patients had positive EGFR expression, majority of which were detected using IHC method (Nakamura et al., 2006).

Among our study patients, serum EGFR $m R N A$ expression was similar in ADC and SCC. Most previous studies have shown higher EGFR expression in squamous cell morphology compared to adenocarcinoma, (Hirsch et al., 2003; Nakamura et al., 2006; Rusch et al., 1997; Ludovini et al., 2013) although others have shown opposite results (Sun et al., 2015; Han et al., 2015). The proportion of ADC patients in the present study group was much higher, hence this may have contributed to the similar baseline EGFR $m R N A$ expression in both histological types.

The patients in the current study did not demonstrate any significant association between serum EGFR $m R N A$ expression and various clinical characteristics such as age, gender, smoking status, disease stage or 
performance status. Results of some previous studies have demonstrated association of EGFR expression with patient characteristics such as female sex, (Suwinski et al., 2012; Arfaoui et al., 2014) smoking status, (Zhuo et al., 2014; Arfaoui et al., 2014) and advanced disease stage, (Sun et al., 2015; Arfaoui et al., 2014; Liang et al., 2012; Traynor et al., 2013) while several others have not. (Hirschet al., 2003; Brabender et al., 2001; Han et al., 2015; Liang et al., 2010). In the few studies that evaluated EGFR expression in blood, most included early stage disease undergoing surgical resection and did not find significant association between serum EGFR expression and clinical characteristics such as age, sex, or pathological subtype (Zhuo et al., 2014; Ciledag et al., 2008; Sasaki et al., 2003; Dziadziuszko et al., 2006). On the other hand, positive correlation of serum EGFR levels (measured by ELISA) with smoking index has been reported (Zhuo et al., 2014).

Following treatment, the patients in the present study showed a significant decline in serum EGFR $m R N A$ levels. Subgroup analysis showed that this decline occurred in both males and females, in all age categories, current and ex-smokers, subjects with smoking index $>250$, in both adenocarcinoma and squamous cell carcinoma lung cancer, and in subjects with relatively better performance status. The trend of EGFR expression following treatment in lung cancer has been sparsely evaluated primarily because most studies were conducted in tumor tissue, hence repeat testing of $E G F R$ expression was not feasible. In serum, $E G F R$ mRNA levels were found to decline significantly following surgical resection in 56 patients with early stage NSCLC (Zhuo et al., 2014).In our patients, although serum EGFR mRNA declined in patients with metastatic as well as non-metastatic disease, the degree of decline was similar between both groups. This may possibly be due to the fact that even in the non-metastatic group, most patients had stage IIIB disease, hence this group probably did not truly reflect the early stage lung cancer.

The baseline serum EGFR $m R N A$ expression in the Gefitinib group was significantly higher than in the chemotherapy group. Both treatment arms however, showed a significant reduction in EGFR expression following treatment; consequently, the post-treatment $E G F R$ levels were similar between both groups. The relationship between EGFR expression and treatment modality has not been well elucidated. Most previous studies have included surgically resected tissue for EGFR expression, and comparisons with any other treatment modality have not been reported. Similarly, data regarding change in EGFR expression following treatment is limited to a solitary study that reported significant decline in serum EGFR expression following surgical resection in 56 patients (Zhuo et al., 2014). To the best of our knowledge, no existing publication has as yet reported on the change in EGFR $m R N A$ expression levels measured in serum following two different treatment modalities in advanced stage NSCLC. Overall, the results of the present study therefore suggest that both chemotherapy and Gefitinib cause a significant reduction in EGFR expression in NSCLC.

We also found that baseline serum EGFR $m R N A$ levels did not predict response to treatment or likelihood of achieving disease control (DC). However, subjects who achieved DC demonstrated significant reduction in serum EGFR mRNA levels from baseline, thereby implying a possible prognostic association. On the other hand, reduction in serum EGFR mRNA levels did not differentiate between responders and non-responders. The utility of EGFR expression in predicting treatment response and DC has been sparsely reported, and a previous study showed that the probability of treatment response was significantly greater in NSCLC on gefitinib and with high EGFR expression compared to those with low expression, although disease control rates were unaffected. In the same study, a subgroup analysis of 14 EGFR mutated patients revealed that higher EGFR expression was associated with response to treatment and better PFS compared to non-responders, thereby indicating that serum EGFR $m R N A$ expression may be a promising parameter for predicting therapeutic response in NSCLC, especially those who are EGFR mutated. On the other hand, lack of correlation between EGFR expression and treatment response or survival was reported in 375 tissue specimens in the Tarceva Lung Cancer Investigation Trial, (Gatzemeier et al., 2007) as well as in a cohort of previously treated Squamous cell lung cancer patients (Chang et al., 2016).

\section{Serum EGFR mRNA expression as a Predictor of Survival Outcomes}

We found that OS and PFS was significantly higher in all patients having baseline serum EGFR $m R N A$ expression $\leq 16.0$-fold-increase compared to those with $>$ 16.0-fold-increase. Similar results were obtained by applying this cut-off value to ADC and SCC groups separately. Compared to patients with low baseline serum EGFR expression $(\leq 16.0)$, patients of NSCLC with high serum EGFR $(>16.0)$ had 2.9 times higher risk of mortality and 1.7 times higher risk of disease progression.

The prognostic role of EGFR expression is as yet, uncertain. Majority of studies in fact, have not shown any significant association of $E G F R$ expression with survival outcomes (Suwinski et al., 2012; Gatzemeier et al., 2007; Rusch et al., 1993; Murray S et al., 2012; Seyhan et al., 2010). A few reports, albeit of relatively small sample size, have shown that higher EGFR expression is associated with better survival (Dziadziuszko et al., 2006; Chang et al., 2016; Shah et al., 2004). In previously treated SCC patients on TKIs, better PFS and OS was seen in patients with high EGFR expression (Chang et al., 2016). The explanation for such an association may be that possibly the loss of expression of these receptors is associated with biologic aggressiveness in lung tumors resulting in adverse outcome for patients with such tumors. On the other hand, studies have also reported worse outcomes associated with high EGFR expression (Sun et al., 2015; Li et al., 2011; Traynor et al., 2013) reported that high EGFR expression had a negative impact on the survival of post- operative NSCLC patients who underwent radiotherapy. They proposed that $E G F R$ expression may relate to radiotherapy resistance and impart a poor outcome. Similarly, positive EGFR expression in tissue was a significant predictor of 
reduced 3-year survival in Chinese females (Sun et al., 2015). It is notable, however, that all the above studies were conducted in the tumor tissue of patients with early stage disease, which is an important distinction from the design of the current study wherein EGFR expression was measured in the serum of advanced stage patients.

Among the two meta-analysis that have been conducted to determine the effect of EGFR expression on survival outcomes in lung cancer, results have been variable. The first meta-analysis (Meert et al., 2002) included 11 studies and 2185 patients and the result just reached significance (HR 1.13, 95\% CI, 1.00-1.28), implying that patients with a tumour not expressing EGFR had a better survival. They reported significant association of EGFR expression with survival only with SCC, unlike our results that showed that survival is associated with EGFR $m R N A$ expression in both ADC and SCC.

The second meta-analysis included 18 studies and 2972 patients (Nakamura et al., 2006). Of note, only three of these studies had included patients with stage IV disease while the remaining had included stages I-IIIB. Six of the 18 studies reported shorter survival with EGFR over-expression, while two studies showed longer survival. Overall, EGFR overexpression was not shown to have significant impact on survival in NSCLC. However, both the above meta-analysis was limited by lack of data for aggregation in few studies, heterogeneity in method of EGFR expression testing, and methods of extrapolation of hazard ratios.

Based on our ROC analysis, the cut-off of baseline serum EGFR $m R N A$ expression level gave a predictive value for mortality as $76 \%$. Previously also, some authors have determined cut-off values based on ROC for testing the role of EGFR expression in survival prediction (Chang et al., 2017; Sasaki et al., 2003; Dziadziuszko et al., 2006). None of the previous reports, however, specified the area under the ROC based on their derived cut-off values.

This study had some limitations. The patient recruitment was not consecutive and had disproportionately higher adenocarcinoma subjects. However, since the sample size was calculated based on all NSCLC, the recruited number of patients were statistically adequate to achieve the primary outcome. Secondly, of the 267 subjects who were initiated on treatment, response assessment could only be done in $65.2 \%(174 / 267)$ subjects as the remaining were unable to complete the treatment schedule. Thirdly, we did not perform EGFR mRNA measurements in tissue specimens and based our results only on serum levels. Fourth, we had very few patients with early-stage disease; hence a stage-wise comparison of EGFR expression between early and late-stage NSCLC was not possible. In spite of these shortcomings, we feel this study provides useful information regarding a promising biomarker that may have prognostic value in patients with advanced NSCLC.

To conclude, serum EGFR $m R N A$ expression is increased in NSCLC and declines following treatment; this is a useful parameter for predicting treatment response and survival outcomes.

\section{Acknowledgements}

This work was supported by an educational grant from the Department of Biotechnology, Govt. of India.

Statement of Financial disclosures and Conflict of interest None of the authors have any conflict of interest to declare.

\section{References}

Amin MB, Edge SB, Greene FL, et al (2017). AJCC Cancer Staging Manual. 8th ed. New York: Springer.

Arfaoui A, Kriaa L, Znaidi N, et al (2014). Over-expression of EGFR is closely correlated to poor prognosis in Tunisian patients with non-small cell lung adenocarcinoma. J Immun Immunochem, 35, 256-68.

Bieche I, Onody P, Tozlu S, et al (2003). Prognostic value of ERBB family mRNA expression in breast carcinomas. Int $J$ Cancer, 106, 758-65.

Brabender J, Danenberg KD, Metzger R, et al (2001). Epidermal growth factor receptor and HER2-neu mRNA expression in non-small cell lung cancer Is correlated with survival. Clin Cancer Res, 7, 1850-5.

Brierley JD, Gospodarowicz MK, Wittekind Ch (2017). UICC TNM Classification of Malignant Tumours. . 8th ed. Oxford: Wiley Blackwell; 2017.

Chandra S, Mohan A, Guleria R, Singh V, Yadav P (2009). Delays during the diagnostic evaluation and treatment of lung cancer. Asian Pacific journal of cancer prevention: Asian Pac J Cancer Prev, 10, 453-6.

Chang H, Oh J, Zhang X, et al (2016). EGFR protein expression using a specific intracellular domain antibody and PTEN and clinical outcomes in squamous cell lung cancer patients with EGFR-tyrosine kinase inhibitor therapy. OncoTargets Ther, 9, 5153-62.

Chang HC, Chen YM, Tseng CC, et al (2017). Impact of epidermal growth factor receptor gene expression level on clinical outcomes in epidermal growth factor receptor mutant lung adenocarcinoma patients taking first-line epidermal growth factor receptor-tyrosine kinase inhibitors. Tumour Biol J Int Soc Oncodevel Biol Med, 39, 1010428317695939.

Chomczynski P, Mackey K (1995). Short technical reports. Modification of the TRI reagent procedure for isolation of RNA from polysaccharide- and proteoglycan-rich sources. Biotechniques, 19, 942-945.

Ciardiello F, Tortora G (2003). Epidermal growth factor receptor (EGFR) as a target in cancer therapy: understanding the role of receptor expression and other molecular determinants that could influence the response to anti-EGFR drugs. Eur J Cancer, 39, 1348-54.

Ciledag A, Kaya A, Yetkin O, et al (2008). The prognostic value of serum epidermal growth factor receptor level in patients with non-small cell lung cancer. Tuberk Toraks, 56, 390-5.

Claret L, Gupta M, Han K, et al (2014). Prediction of overall survival or progression free survival by disease control rate at week 8 is independent of ethnicity: Western versus Chinese patients with first-line non-small cell lung cancer treated with chemotherapy with or without bevacizumab. J Clin Pharmacol, 54, 253-7.

Detterbeck FC, Boffa DJ, Kim AW, Tanoue LT (2017). The eighth edition lung cancer stage classification. Chest, 151, 193-203.

Dziadziuszko R, Witta SE, Cappuzzo F, et al (2006). Epidermal growth factor receptor messenger RNA expression, gene dosage, and gefitinib sensitivity in non-small cell lung 
cancer. Clin Cancer Res, 12, 3078-84.

Eisenhauer EA, Therasse P, Bogaerts J, et al (2009). New response evaluation criteria in solid tumours: revised RECIST guideline (version 1.1). Eur J Cancer, 45, 228-47.

Fontanini G, De Laurentiis M, Vignati S, et al (1998). Evaluation of epidermal growth factor-related growth factors and receptors and of neoangiogenesis in completely resected stage I-IIIA non-small-cell lung cancer: amphiregulin and microvessel count are independent prognostic indicators of survival. Clin Cancer Res, 4, 241-9.

Gaber R, Watermann I, Kugler C, et al (2014). Correlation of EGFR expression, gene copy number and clinicopathological status in NSCLC. Diagn Pathol, 9, 165.

Gatzemeier U, Pluzanska A, Szczesna A, et al (2007). Phase III study of erlotinib in combination with cisplatin and gemcitabine in advanced non-small-cell lung cancer: the Tarceva Lung Cancer Investigation Trial. J Clin Oncol, 25, 1545-52.

Gazdar AF (2009). Personalized medicine and inhibition of EGFR signaling in lung cancer. $N$ Engl JMed, 361, 1018-20.

Guleria JS, Gopinath N, Talwar JR, et al (1971). Bronchial carcinoma--an analysis of 120 cases. J Assoc Physic India, 19, 251-5.

Han YH, Abdul Hamid MR, Telisinghe PU, Haji Hussin JB, Mabruk M (2015). Overexpression of EGFR protein in Bruneian lung cancer patients. Asian Pac J Cancer Prev, 16, 233-7.

Hirsch FR, Varella-Garcia M, Bunn PA, et al (2003). Epidermal growth factor receptor in non-small-cell lung carcinomas: correlation between gene copy number and protein expression and impact on prognosis. J Clin Oncol, 21, 3798-3807.

Jindal SK BD (1990). Clinical spectrum of primary lung cancer - Review of Chandigarh experience of 10 years. Lung India. $1990 ; 8$.

Jindal SK, Malik SK, Dhand R, et al (1982). Bronchogenic carcinoma in Northern India. Thorax, 37, 343-7.

Karnofsky DA, JH B (1949). The clinical evaluation of chemotherapeutic agents in cancer. In: CM M, ed. In Evaluation of chemotherapeutic agents. New York: Columbia University Press; pp 191-205.

Lee SM (2006). Is EGFR expression important in non-small cell lung cancer?. Thorax, 61, 98-99.

Li AR, Chitale D, Riely GJ, et al (2008). EGFR mutations in lung adenocarcinomas: clinical testing experience and relationship to EGFR gene copy number and immunohistochemical expression. J Mol Diagn, 10, 242-8.

Li F, Liu Y, Chen H, et al (2011). EGFR and COX-2 protein expression in non-small cell lung cancer and the correlation with clinical features. J Exp Clin Cancer Res, 30, 27.

Liang H, Zhang J, Shao C, et al (2012). Differential expression of RBM5, EGFR and KRAS mRNA and protein in non-small cell lung cancer tissues. J Exp Clin Cancer Res, 31, 36.

Liang Z, Zhang J, Zeng X, et al (2010). Relationship between EGFR expression, copy number and mutation in lung adenocarcinomas. BMC Cancer, 10, 376.

Livak KJ, Schmittgen TD (2001). Analysis of relative gene expression data using real-time quantitative PCR and the 2(-Delta Delta C(T)) Method. Methods, 25, 402-8.

Ludovini V, Flacco A, Bianconi F, et al (2013). Concomitant high gene copy number and protein overexpression of IGF1R and EGFR negatively affect disease-free survival of surgically resected non-small-cell-lung cancer patients. Cancer Chemother Pharmacol, 71, 671-80.

Meert AP, Martin B, Delmotte P, et al (2002). The role of EGF-R expression on patient survival in lung cancer: a systematic review with meta-analysis. Eur Respir J, 20, 975-981.
Murray S, Karavasilis V, Bobos M, et al (2012). Molecular predictors of response to tyrosine kinase inhibitors in patients with Non-Small-Cell Lung Cancer. J Exp Clin Cancer Res, 31, 77.

Nakamura H, Kawasaki N, Taguchi M, Kabasawa K (2006). Survival impact of epidermal growth factor receptor overexpression in patients with non-small cell lung cancer: a meta-analysis. Thorax, 61, 140-5.

Nakashima K, Horita N, Nagai K, et al (2016). Progressionfree survival, response rate, and disease control rate as predictors of overall survival in phase III randomized controlled trials evaluating the first-line chemotherapy for advanced, locally advanced, and recurrent non-small cell lung carcinoma. J Thorac Oncol, 11, 1574-85.

Oken MM, Creech RH, Tormey DC, et al (1982). Toxicity and response criteria of the Eastern Cooperative Oncology Group. Am J Clin Oncol, 5, 649-55.

Pazdur R (2008). Endpoints for assessing drug activity in clinical trials. Oncologist, 13, 19-21.

Rami-Porta R (2016). IASLC Staging Manual in Thoracic Oncology. North Fort Myers: Editorial Rx Press; 2016.

Reddy KS, Gupta PC (2004). Report on tobacco control in India In: Ministry of Health and Family Welfare, ed. New Delhi. 2004.

Rusch V, Baselga J, Cordon-Cardo C, et al (1993). Differential expression of the epidermal growth factor receptor and its ligands in primary non-small cell lung cancers and adjacent benign lung. Cancer Res, 53, 2379-85.

Rusch V, Klimstra D, Venkatraman E, et al (1997). Overexpression of the epidermal growth factor receptor and its ligand transforming growth factor alpha is frequent in resectable non-small cell lung cancer but does not predict tumor progression. Clin Cancer Res, 3, 515-22.

Sasaki H, Yukiue H, Mizuno K, et al (2003). Elevated serum epidermal growth factor receptor level is correlated with lymph node metastasis in lung cancer. Int J Clin Oncol, 8, 79-82.

Seyhan EC, Altin S, Cetinkaya E, et al (2010). Prognostic value of epidermal growth factor receptor expression in operable non-small cell lung carcinoma. Multidisciplinary Respiratory Med, 5, 305-11.

Shah L, Walter KL, Borczuk AC, et al (2004). Expression of syndecan-1 and expression of epidermal growth factor receptor are associated with survival in patients with nonsmall cell lung carcinoma. Cancer, 101, 1632-8.

Shimkhada R, Peabody JW (2003). Tobacco control in India. Bull World Health Organ, 81, 48-52.

Singh N, Aggarwal AN, Gupta D, Behera D, Jindal SK (2012). Quantified smoking status and non-small cell lung cancer stage at presentation: analysis of a North Indian cohort and a systematic review of literature. J Thoracic Dis, 4, 474-84.

Sun G, Liu B, He J, Zhao X, Li B (2015). Expression of EGFR is closely related to reduced 3-year survival rate in Chinese female NSCLC. Int Med Exp Clin Res, 21, 2225-31.

Suwinski R, Klusek A, Tyszkiewicz T, et al (2012). Gene expression from bronchoscopy obtained tumour samples as a predictor of outcome in advanced inoperable lung cancer. PLoS One, 7, e41379.

Traynor AM, Weigel TL, Oettel KR, et al (2013). Nuclear EGFR protein expression predicts poor survival in early stage non-small cell lung cancer. Lung Cancer, 81, 138-41.

U.S. Department of Health and Human Services: Food and Drug Administration. Center for Drug Evaluation and Research (CDER). Guidance for industry: clinical trial endpoints for the approval of cancer drugs and biologics. http://www. fda.gov/downloads/Drugs/.../Guidances/ucm071590.pdf. .Published May 2007. 
Zhuo Y, Guo Q, Song P, et al (2014). Correlation study and significance of the EGFR expression in serum, lymph nodes and tumor tissue of NSCLC. Thoracic Cancer, 5, 31-7.

\section{(ब)}

This work is licensed under a Creative Commons AttributionNon Commercial 4.0 International License. 